\title{
Strategi Pencegahan dan Pemberantasan Korupsi di Pemerintah Kota Kupang, Provinsi Nusa Tenggara Timur
}

\author{
Strategies of Prevention and Eradication of Corruption \\ in Kota Kupang Government, East Nusa Tenggara
}

\author{
Jefirstson Richset Riwukore, ${ }^{1}$ Hilda Manafe, ${ }^{2}$ Fellyanus Habaora, ${ }^{3}$ \\ Yohanes Susanto, ${ }^{4}$ dan Tien Yustini ${ }^{5}$ \\ 1jefritson@uigm.ac.id \\ Universitas Indo Global Mandiri \\ Jl. Jenderal Sudirman, No. 629 Palembang, Sumatera Selatan, 30129 \\ 2hildamanafe@gmail.com \\ Anggota DPD RI Periode 2019-2024 \\ Kantor DPD RI, Jl. Gatot Subroto, Senayan, Jakarta 10270 \\ 3fellyanus_habaora@apps.ipb.ac.id (correspondence author) \\ Sekolah Pascasarjana IImu Produksi dan Teknologi Peternakan IPB \\ Jl. Raya Dramaga, Babakan, Kec. Dramaga, Bogor, Jawa Barat, 16680 \\ ${ }^{4}$ susantoyohanes@gmail.com \\ Universitas Bina Insan Lubuklinggau \\ Jl. Jendral Besar Moh. Soeharto KM. 13, Kota Lubuk Linggau, Sumatera Selatan 36125 \\ 5tien_yustini@uigm.ac.id \\ Universitas Indo Global Mandiri \\ Jl. Jenderal Sudirman, No. 629 Palembang, Sumatera Selatan, 30129
}

Naskah diterima: 2 Februari 2020 | Naskah direvisi: 2 Juni 2020 | Naskah diterbitkan: 31 Desember 2020

\begin{abstract}
Kupang is the most corrupt city based on a survey by Transparency International Indonesia. The problem is what are the causes of corruption in Kupang City? And what are the strategies the Kupang City Government could adopt to prevent and eradicate corruption in its regions? This research identifies corruption behavior based on terminology, behavioral factors, a mode that is often used to commit corruption, and what must be done to overcome it. The method used in this research was an explanatory method using secondary data. Qualitative analysis was then conducted using SWOT analysis. Results showed that corruption is an action to enrich themselves, their families, groups, and corporations by violating rules, norms, and human rights through the exploitation of economic, political, socio-cultural, and environmental resources by maximizing the potential of their resources (position, network, and power). Factors that cause corruption are individual motivations and poor government organization systems and will increase the influence of corruption if it is supported by an environment in which individuals and poor systems are located. Based on this, the strategies that can be carried out by Kupang City Government are to immediately carry out an MoU with law enforcement institutions; to use electronic or online systems for all financial transactions within the government; to form a task force against extortion in the government; to enforce financial reporting for all officials within the government; to have a more efficient government budget for a dual and unnecessary function to open access for public monitoring through electronic database; and to have an integrity pact-based performance measurement.
\end{abstract}




\begin{abstract}
Abstrak: Penelitian ini mengidentifikasi perilaku korupsi berdasarkan terminologi, faktor penyebab perilaku, modus yang sering dilakukan untuk melakukan korupsi, dan apa yang harus dilakukan untuk mengatasinya. Metode yang digunakan untuk melakukan penelitian ini adalah penelitian eksplanatif menggunakan data sekunder. Analisis secara kualitatif dilakukan dengan menggunakan analisis SWOT. Hasil penelitian menunjukkan bahwa korupsi adalah tindakan untuk memperkaya diri, keluarga, kelompok, dan korporasinya dengan cara melanggar aturan, melanggar norma, melanggar hak asasi manusia melalui eksploitasi sumber daya ekonomi, politik, sosial budaya, dan lingkungan hidup dengan memaksimalkan potensi sumber daya yang dimiliki (jabatan, jaringan, dan kekuasaan). Faktor penyebab korupsi adalah motivasi individu dan sistem organisasi pemerintah yang buruk, dan akan semakin meningkat pengaruh korupsi jika didukung oleh lingkungan di mana individu dan sistem yang buruk berada. Berdasarkan hal tersebut maka strategi yang dapat dilakukan oleh Pemerintah Kota Kupang adalah segera melakukan Memorandum of Understanding dengan lembaga penegakan hukum; segala transaksi keuangan di pemerintahan menggunakan transaksi elektronik atau online; pemerintah membentuk gugus tugas pemberantasan pungli di pemerintahan; memberlakukan pelaporan keuangan pada pejabat di lingkup pemerintahan; efisiensi anggaran pemerintahan yang ganda fungsi dan tidak bermanfaat; membuka akses pemantauan publik melalui basis data elektronik; dan pengukuran kinerja berbasis pakta integritas.
\end{abstract}

Kata Kunci: korupsi; Kota Kupang; pemberantasan korupsi; pencegahan korupsi

\section{Pendahuluan}

Peraturan Pemerintah Nomor 99 Tahun 2012 tentang Perubahan Kedua atas Peraturan Pemerintah Nomor 32 Tahun 1999 tentang Syarat dan Tata Cara Pelaksanaan Hak Warga Binaan Pemasyarakatan menyatakan korupsi sebagai kejahatan luar biasa, sejajar dengan tindak pidana terorisme, narkotika dan prekursor narkotika, psikotropika, kejahatan terhadap keamanan negara dan kejahatan hak asasi manusia yang berat, dan kejahatan transnasional organisasi lainnya. Korupsi mengakibatkan kerugian yang besar bagi negara dan masyarakat, atau menimbulkan korban banyak, kepanikan, kecemasan, atau ketakutan yang luar biasa kepada masyarakat.

Indonesia merupakan negara yang memiliki nilai Indeks Persepsi Korupsi tertinggi di kawasan Asia Tenggara. Rerata negara di Asia Tenggara menunjukkan tren perilaku korupsi yang semakin menurun, sedangkan di Indonesia menunjukkan tren peningkatan. Komisi Pemberantasan Korupsi (KPK) tahun
2018 melaporkan bahwa perkembangan Indeks Perilaku Korupsi di Indonesia telah menyentuh angka 2,0 untuk periode tahun 1999-2017, sedangkan Vietnam, China, Thailand, Kamboja, Filipina, dan Malaysia menunjukkan indeks perilaku korupsi cenderung menurun sampai minus nol. Periode tahun 2014-2017, perkara korupsi yang ditangani KPK sebanyak 618 kasus yang terdiri atas kasus penyuapan $(55,02 \%)$, kasus pengadaan barang dan jasa (26,54\%), kasus penyalahgunaan anggaran $(7,44 \%)$, kasus perizinan $(3,40 \%)$, kasus pungutan $(3,40 \%)$, kasus tindak pidana pencucian uang $(3,07 \%)$, dan kasus merintangi proses KPK $(1,13 \%)$. Sementara itu, pelaku perkara korupsi dengan persentase tertinggi adalah swasta (25,37\%), eselon I sampai III (23,13\%), anggota DPR/DPRD (20\%), dan sisanya dilakukan oleh kepala lembaga/ kementerian, walikota/bupati dan wakil, gubernur, hakim, komisioner, duta besar, dan lain sebagainya (Panjaitan, 2018). Dengan demikian perilaku korupsi di Indonesia sangat terkait erat dengan 
dimensi penyuapan, pengadaan barang dan jasa, dan penyalahgunaan anggaran yang umumnya dilakukan oleh pihak swasta dan pegawai pemerintahan, mulai eselon paling bawah sampai eselon paling tinggi. Hariyanto (2012: 119) menjelaskan bahwa korupsi di Indonesia bermuara pada rendahnya gaji yang diterima oleh pegawai. Ini telah berlangsung sejak Indonesia merdeka hingga sekarang. Secara faktual gaji yang diterima oleh pegawai pada setiap bulannya hanya mampu untuk bertahan hidup paling lama setengah bulan sehingga diperlukan daya usaha untuk menutupi kekurangan setengah bulannya lagi.

Pada tahun 2016 Indonesia Corruption Watch merilis data kategori penanganan kasus korupsi terbanyak di Indonesia sepanjang tahun 2015, yang menempatkan provinsi Nusa Tenggara Timur (NTT) pada urutan ke-empat setelah provinsi Jawa Barat, Sumatera Utara, dan Jawa Timur (Redaksi Timor, 2016). Identitas negatif provinsi NTT sebagai provinsi terkorup naik 15 poin dari data Fitra di tahun 2012 yang menempatkan provinsi NTT urutan ke-19 sebagai provinsi terkorup di Indonesia ("Ini dia peringkat," 2012). Berdasarkan data Pusat Anti Korupsi Undana tahun 2018 pelaku korupsi di NTT pada umumnya adalah Pegawai Negeri Sipil (52,08\%), swasta (35,42\%), Pejabat/Pegawai BUMD (10,42\%), dan Anggota DPRD (2,08\%) (Rambu, 2018b).

Yang lebih mengejutkan adalah survei Transparency International Indonesia pada 50 kota di Indonesia menyimpulkan bahwa Kota Kupang merupakan kota paling korup di Indonesia (Ama \& PR, 2010) sehingga Kota Kupang disinyalir menjadi target operasi KPK sebagai wilayah otonom yang perlu diwaspadai tingkat korupsinya. Banyak kasus korupsi di Kota Kupang yang masih tersembunyi namun dirasakan masyarakat (Assegaf, 2009; Portal NTT, 2016). Hal ini dijelaskan Pradana (2014: 186) dalam penelitiannya tentang transparansi informasi APBD Kota Kupang periode 2012-2013 bahwa Pemerintah Kota (Pemkot) Kupang menutup akses informasi APBD terhadap publik karena harus melalui persetujuan dari Walikota Kupang saat itu, Jonas Salean.

Namun begitu, pelaku korupsi semakin cerdik untuk mengubah motif dan modus dalam melakukan korupsi seperti memunculkan item anggaran baru yang memiliki fungsi kegiatan yang sama, pungutan liar (pungli) berbasis dana sukarela atau legalisasi pungutan, dan katebelece. Selama ini belum ada upaya yang sistematis dari Pemkot Kupang untuk menyelesaikan dinamika (motif dan modus) korupsi. Kajian akan berangkat dari proses mengidentifikasi perilaku korupsi di Kota Kupang berdasarkan terminologi, faktor penyebab perilaku, modus yang sering dilakukan untuk melakukan korupsi, dan apa yang harus dilakukan untuk mengatasinya. Dengan begitu tulisan ini berangkat dari pertanyaan penelitian: strategi apa yang dapat dilakukan oleh Pemkot Kupang untuk mencegah dan memberantas korupsi di masa depan?

Kajian ini termasuk dalam penggolongan penelitian studi literatur untuk mengungkap berbagai teori-teori yang relevan dengan permasalahan yang sedang diteliti. Teknik ini dilakukan dengan cara membaca, mempelajari, dan mengkaji literatur-literatur yang berhubungan dengan modus dan motif korupsi, serta terkait pencegahan dan pemberantasan korupsi. Straus dan Corbin (2009: 39) menyatakan bahwa pengkajian literatur untuk suatu kepentingan dapat berupa literatur teknis dan literatur nonteknis. Literatur teknis seperti laporan tentang kajian penelitian dan karya tulis profesional atau disipliner dalam bentuk makalah teoretis atau filosofis, sedangkan literatur nonteknis seperti biografi, buku harian, dokumen, naskah, catatan, katalog, dan materi lainnya yang dapat digunakan sebagai data utama atau sebagai pendukung penelitian. Jenis data yang digunakan dalam penelitian ini adalah data 
sekunder (diperoleh dari sumber yang terkait dengan penelitian ini), yaitu: buku, jurnal, artikel laporan penelitian, dan situssitus di internet. Data diperoleh melalui pencarian informasi di internet. Output dari studi literatur ini adalah terkoleksinya referensi yang relevan dengan tujuan penelitian, yaitu memperkuat permasalahan serta sebagai dasar teori dalam melakukan studi dan juga menjadi dasar untuk menyusun konsep strategi pencegahan dan pemberantasan korupsi di Pemkot Kupang.

Data yang diperoleh kemudian dianalisis secara deskriptif kualitatif. Penyusunan konsep strategi dalam analisis data kualitatif ini merupakan satu kesatuan analisis yang mendalam berdasarkan analisis SWOT. Analisis SWOT merupakan alat formulasi strategi yang digunakan untuk identifikasi berbagai faktor secara sistematis untuk merumuskan strategi. Analisis ini didasarkan pada logika yang bisa memaksimalkan kekuatan (strengths) dan peluang (opportunities), namun secara bersamaan dapat meminimalkan kelemahan (weaknesses) dan ancaman (threats) (Rangkuti, 2006: 18-19). Melalui analisis SWOT akan membantu penulis mencari formula strategi yang dapat dilakukan Pemkot Kupang untuk mencegah dan memberantas korupsi di wilayahnya.

\section{Dimensi Korupsi}

Secara umum tidak ada definisi yang tegas mengenai korupsi itu sendiri dalam peraturan perundang-undangan. Namun, Pasal 2 Undang-Undang Nomor 31 Tahun 1999 jo Undang-Undang Nomor 20 Tahun 2001 tentang Perubahan Kedua Atas Undang-Undang Nomor 31 Tahun 1999 menyiratkan bahwa tindak pidana korupsi meliputi siapa saja (setiap orang) yang secara sadar maupun tidak sadar melakukan tindakan bertentangan dengan hukum yang bertujuan untuk memperkaya diri sendiri, kroni, maupun golongan atau orang lain, dan juga suatu korporasi atau lembaga yang merugikan perekonomian maupun keuangan negara. Aturan ini menjelaskan bahwa manifestasi korupsi terwujud dari penyalahgunaan sumber daya kekuasaan/kewenangan seperti fasilitas maupun perangkatnya berdasarkan kekuasaan maupun kewenangan yang melekat ke dirinya agar kepentingan pribadinya, keluarganya, dan kroni/golongannya dipenuhi. Pelaku korupsi bisa berasal dari semua dimensi, baik di segmen politik, birokrasi, dan ekonomi untuk perbuatan yang sama (Setiyono, 2017: 28).

Shah dan Schacter (2004: 43) menyatakan bahwa korupsi terjadi atas tiga kategori, yaitu: (1) grand corruption, yaitu perilaku penyalahgunaan kekuasaan/ kewenangan menggunakan sumber daya publik secara masif yang dilakukan oleh sejumlah pejabat; (2) state capture atau influence peddling, yaitu kolusi antara swasta terhadap sejumlah pejabat publik untuk memperoleh keuntungan pribadi maupun keuntungan secara bersamasama; dan (3) bureaucratic corruption atau petty corruption, yaitu korupsi yang terjadi atas kemudahan yang diberikan dalam suatu birokrasi seperti melalui suap atau sogok atau mengalikan sejumlah sumber daya ke pihak tertentu karena pertimbangan untuk memperoleh suap atau keuntungan yang kecil.

Dimensi korupsi dapat dilihat juga dari perspektif analysis context used, yaitu: public office to centred, market to centred, dan public interest to centred (Rothstein \& Varraich, 2014; Retnowati \& Utami, 2014: 30; Setiyono, 2017: 35; Herdiana, 2019: 5). Teori public office to centred menjelaskan bahwa corruption (korupsi) adalah perilaku yang menyimpang oleh pejabat publik terhadap aturan formal yang berlaku untuk tujuan keuntungan sendiri (pribadi), seperti gratifikasi, nepotisme, dan tidak prosedural (maladministrasi). Teori market to centred menjelaskan bahwa corruption (korupsi) merupakan penyalahgunaan kewenangan melalui jabatan dari seorang pejabat negara 
atau publik untuk kepentingan pribadi dengan cara mengoptimalkan kemampuan sumber daya di birokrasinya dalam sikap monopoli dan penerbitan kebijakan, seperti pajak, retribusi, subsidi, bahkan privatisasi. Kemudian teori public interest to centred menjelaskan corruption (korupsi) sebagai perbedaan pelayanan dari seorang pejabat atau pemegang kekuasaan karena lebih mengistimewakan orang (siapapun) yang memberikan keuntungan berupa imbalan sehingga menciptakan prinsip inequality (ketidakmerataan dan ketidakadilan) dalam melayani masyarakat.

Berdasarkan uraian di atas maka dapat dijelaskan bahwa korupsi merupakan tindakan untuk memperkaya diri, keluarga, kelompok, dan korporasinya dengan cara melanggar aturan, melanggar norma, melanggar hak asasi manusia melalui eksploitasi sumber daya ekonomi, politik, sosial budaya, dan lingkungan hidup dengan memaksimalkan potensi sumber daya yang ada (jabatan, jaringan, dan kekuasaan).

\section{Modus Korupsi}

Indonesia Corruption Watch (ICW) melaporkan bahwa modus atau cara korupsi yang sering dilakukan antara lain melalui penyalahgunaan anggaran, penggelapan, mark-up, penyalahgunaan wewenang, laporan fiktif, suap atau gratifikasi, pemerasan, mark-down, pungli, dan anggaran ganda (Tashandra, 2016). Setiyono (2017: 39-40) menyatakan umumnya modus korupsi yang sering ditemukan pada setiap kasus terdiri atas empat cara (modus), yaitu:

Mark-up dan mark-down, pertanggungjawaban fiktif, abuse of power, dan penggelapan. Mark-up dilakukan melalui cara menaikkan anggaran pada pembiayaan (pengeluaran) anggaran yang tidak seharusnya agar menguntungkan kepentingan pribadi, dan keuangan negara atau keuangan daerah dirugikan. Modus mark-down dengan cara menurunkan nilai potensi pendapatan yang tidak berdasarkan fakta lapangan di mana ada peningkatan pendapatan melebihi dari potensi yang ada. Laporan fiktif sering dilakukan dengan cara melaporkan realisasi anggaran tidak berdasarkan kenyataannya. Modus ini paling banyak terjadi di perjalanan dinas.

1) Redundant (menggandakan) dilakukan melalui menggandakan jenis anggaran yang berbeda-beda tetapi untuk satu fungsi misalnya pos anggaran untuk jaminan kesehatan tetapi pada pos anggaran lain dimunculkan item anggaran dengan nama tunjangan asuransi kesehatan. Sebenarnya pos anggaran untuk jaminan kesehatan dan tunjangan asuransi kesehatan merupakan fungsi yang sama yaitu anggaran bagi kesehatan anggota legislatif. Contoh lain, menitipkan pos anggaran ke eksekutif atau pemerintah daerah melalui item anggaran bantuan kelembagaan.

2) Menciptakan pos mata anggaran baru yang tidak sesuai dengan peraturan perundang-undangan, seperti Peraturan Pemerintah Nomor 110 Tahun 2000 tentang Kedudukan Keuangan Dewan Perwakilan Rakyat Daerah. Contoh: mengalokasikan pos anggaran untuk purna bakti/pensiun, dan/atau rumah dinas yang hanya untuk pimpinan DPR/DPRD tetapi diciptakan item anggaran rumah dinas untuk semua anggota DPR/DPRD.

3) Korupsi dalam keuangan program kegiatan, seperti pemalsuan tiket perjalan dinas, surat perintah perjalanan dinas fiktif, dan laporan pertanggungjawaban fiktif. Modus korupsi ini umumnya dilakukan melalui manipulasi dokumen keuangan dalam realisasi $A P B D$, pelaksanaan kegiatan fiktif untuk memperkaya diri sendiri atau sekelompok orang sehingga merugikan keuangan daerah atau keuangan negara. 
Modus korupsi satu sampai tiga merupakan tindakan korupsi sesuai kesepakatan antara dua belah pihak seperti eksekutif dengan legislatif untuk mencari celah hukum dan kewenangan yang terkadang tumpang tindih untuk kepentingan dua pihak. Korupsi jenis ini dianggap korupsi legal karena dipayungi oleh peraturan perundangan. Pope (2000: 15) menyatakan bahwa modus korupsi terjadi atas dua kategori, yaitu: (1) korupsi karena dinamika yang didukung peraturan perundangan, dan (2) modus korupsi karena tindakan korupsi yang melanggar peraturan perundang-undangan. Setiyono (2017: 37) menjelaskan bahwa korupsi karena dinamika menguntungkan pihak yang melakukan korupsi karena dipayungi peraturan perundangan, dan korupsi karena tindakan nyata korupsi karena terbukti melanggar perundangan dan memperkaya diri sendiri. Dua modus korupsi tersebut ada pada setiap hierarki kelembagaan pemerintah dan menyebabkan kerugian pada keuangan daerah dan negara dari kecil sampai besar.

\section{Faktor-Faktor Penyebab Korupsi}

Ada dua penyebab seseorang melakukan korupsi, pertama, karena adanya kebutuhan (corruption by need), yaitu tindakan untuk memeras (ada unsur paksaan) dalam melakukan kegiatankegiatan pelayanan publik, seperti suap untuk kemudahan memperoleh administrasi kependudukan, maupun menyogok untuk memperoleh pelayanan istimewa di rumah sakit. Kedua, korupsi juga disebabkan karena adanya sikap serakah (corruption by greed), yaitu kongkalikong (kerja sama) dalam mendapatkan keuntungan pribadi melalui kolusi yang saling menguntungkan dan melibatkan sejumlah aktor, seperti kolusi proyek dan jabatan di pemerintahan (Bauhr \& Nasiritousi, 2011: 2-3). Corruption by greed lebih tersembunyi dan sistematis dibandingkan corruption by need.
World Bank (2003: 5) menyatakan bahwa penyebab seseorang melakukan korupsi karena adanya motivasi personal dan bekerja pada sistem yang buruk. Motivasi personal dipengaruhi oleh keinginan untuk mendapatkan keuntungan yang paling tinggi dibandingkan orang lain dengan cara yang cepat melalui penggelapan sejumlah uang untuk tujuan dan kepentingan pribadinya. Setiyono (2017: 55) menyatakan korupsi yang dipengaruhi motivasi personal disebabkan karena menghindari denda atau penalti dari pajak, atau pejabat (politisi) yang takut jika disaat pensiunnya nanti tidak menerima pensiun atau dana talangan hari tua dan/ atau uang jaminan standar hidup mereka, pembayaran kredit, biaya pendidikan, dan sebagainya. Sistem yang buruk memengaruhi seseorang untuk melakukan korupsi karena adanya kesempatan korupsi dari kewenangan yang dimiliki, seperti desentralisasi dan otonomi daerah pada penggunaan APBD, pengelolaan perusahaan daerah, perizinan, dan lain sebagainya. Sistem yang buruk ini tercipta karena pengelolaan anggaran publik yang tidak akuntabel dan transparan, serta lemahnya penegakan hukum daerah setempat. Badan Pengawas Keuangan dan Pembangunan (2002) menyatakan bahwa selain aspek individu dan sistem (organisasi) yang buruk, yang juga sangat berbahaya adalah jika terjadi sikap permisif dari lingkungan terhadap kesalahan personal dan organisasi.

Berdasarkan aspek individu, seseorang melakukan korupsi dipengaruhi sikap tamak manusia, moral yang kurang kuat, penghasilan yang kurang mencukupi, kebutuhan hidup yang mendesak, gaya hidup yang konsumtif, malas, dan ajaran agama yang kurang diterapkan. Sistem yang buruk tercipta karena kurang adanya sikap keteladanan pimpinan, tidak adanya kultur organisasi yang benar, kurang memadainya sistem akuntabilitas di instansi pemerintah, kelemahan sistem pengendalian manajemen, dan 
manajemen yang cenderung menutupi korupsi di dalam organisasi. Kondisi ini akan semakin buruk jika bertemu dengan nilai sosial kemasyarakatan yang kondusif untuk perilaku koruptif, seperti: Masyarakat yang menghargai seseorang hanya berdasarkan status sosial maupun kekayaan. Hal ini membuat seseorang atau komunitas menjadi tidak peka terhadap sumber kekayaan yang diperoleh dari seseorang/komunitas yang melakukan korupsi; (2) Masyarakat yang menganggap bahwa yang dirugikan perilaku korupsi adalah negara, bukan masyarakat. Masyarakat tidak menyadari bahwa korupsi yang menyebabkan anggaran pembangunan berkurang; (3) Masyarakat menganggap bahwa pemberantasan korupsi merupakan urusan penegak hukum atau pemerintah, tidak memerlukan partisipasi publik; dan (4) Masyarakat yang lemah jika berkaitan dengan peraturan yang berdampak kepada kelompok mereka sendiri, kualitas aturan perundangan yang lemah, aturan perundangan yang tidak tersosialisasi dengan baik, sanksi hukum yang tumpul, implementasi sanksi yang berdasarkan kepentingan dan pamrih, monitor dan evaluasi implementasi undang-undang yang lemah.

\section{Modus dan Faktor Penyebab Korupsi di Kota Kupang}

Korupsi di Kota Kupang umumnya terjadi di pemerintahan. Beberapa isu politik dinasti dan korupsi menjadi isu utama saat pemilihan kepala daerah (walikota dan wakil walikota) pada tahun 2017, dan saat pemilihan anggota legislatif DPRD Kota Kupang pada tahun 2019. Pola korupsi yang terjadi di Kota Kupang dan NTT secara umum disebabkan karena penyalahgunaan kekuasaan sehingga menyebabkan kerugian negara dan adanya transaksi balas jasa politik, kongkalikong antara kontraktor (swasta) dan aparatur negara, dan dinasti politik keluarga (Assegaf, 2009; Khadafy, 2012; Nope, 2018; Wahyono, 2019). Hal ini terlihat dari kasus-kasus yang diberitakan di media massa pada tahun 2018 sampai dengan 2020, diantaranya berbentuk:

1) Mark-up dan mark-down. Kasus korupsi mark-up yang masih dalam penyelidikan adalah dugaan penyimpangan yang berpotensi merugikan keuangan negara pada kegiatan Wali Kota Cup 2017 yang diduga merugikan negara sebesar Rp114.644.365.000 (Jahang, 2020). Dalam event Walikota Cup I 2017 menghabiskan dana Rp750 juta lebih. Laporan realisasinya diduga terjadi mark-up harga, salah satunya untuk biaya konsumsi, yang realisasi riil hanya sekitar Rp50 juta, namun dalam laporan mencapai Rp130 juta (Rambu, 2018a).

2) Korupsi dalam keuangan program kegiatan, seperti pemalsuan tiket perjalanan dinas, surat perintah perjalanan dinas fiktif, dan laporan pertanggungjawaban fiktif. Misalnya dalam kasus pengelolaan dana bantuan operasional sekolah (BOS) tahun anggaran 2018 pada SMP Negeri 3 Kupang (Jahang, 2020). Tersangkanya adalah Kepala SD Inpres Liliba dan Kepala SD Inpres Naimata yang menaikkan harga dan volume barang yang dibeli, juga melakukan pembelanjaan fiktif yang tidak sesuai dengan ketentuan yang berlaku sehingga merugikan keuangan negara hingga Rp149 juta (Kaha, 2018). Kasus lain adalah kegiatan Membina Ekonomi Keluarga Sejahtera (MEKAR) yang merupakan program PT PNM (BUMN). Diduga terjadi pembayaran fiktif terhadap penerima yang tidak ada, oleh Kantor Cabang Maulafa yang terjadi di Kota Kupang (Jahang, 2020).

3) Kolusi dan nepotisme dalam penentuan pemenang tender. Misalnya dalam indikasi pengaturan penetapan pemenang sejumlah paket pekerjaan di lingkungan Dinas Pekerjaan Umum dan Perumahan Rakyat Kota Kupang Tahun 
2020 (Supriyanto, 2020). Dalam proses pelelangan pekerjaan jasa konstruksi di Dinas PUPR, terindikasi ada kolusi dan nepotisme yang dilakukan oleh Panitia Pelelangan (Pokja) di lingkungan Dinas PUPR di mana dalam hal pemenang tender ada banyak peserta/rekanan yang urutan terakhir yang ditetapkan oleh Pokja sebagai pemenang (“Terindikasi KKN," 2020).

\section{Strategi Pemerintah Kota Kupang dalam Mencegah dan Memberantas Korupsi}

Penyelenggaraan

pemerintahan

yang baik (good governance) adalah pemerintahan yang memberikan berbagai kemudahan, kepastian, dan bersih dalam menyediakan pelayanan dan perlindungan dari berbagai tindakan sewenang-wenang baik atas diri, hak, ataupun harta bendanya (Fauzan, Bahtaruddin, \& Nuraini, 2012: 449). Oleh karena itu sangat wajar apabila tuntutan penyusunan kebijakan pemerintah yang bersih dalam kerangka rencana aksi daerah pemberantasan korupsi terutama ditujukan pada pembaharuan administrasi negara dan juga penegakan hukum melalui penyusunan strategi yang berbasis dinamika daerah setempat.

Untuk menemukan strategi yang tepat, maka perlu dijabarkan faktor-faktor yang akan memengaruhi upaya Pemkot Kupang dalam mencegah dan memberantas korupsi. Berdasarkan penelusuran penulis pada situs resmi Pemkot Kupang, kekuatan Pemkot Kupang terletak pada: (1) Pemkot Kupang memiliki badan pemeriksa keuangan yang bersifat semi independen, yaitu Badan Inspektorat Kota Kupang, sedangkan di tingkat badan, kantor, dan dinas masing-masing memiliki Satuan Pengendali Internal (SPI); (2) Kepala Daerah memiliki kelembagaan pimpinan daerah (Forkompimda) bersama Kejaksaan, Pengadilan Negeri, dan Kepolisian; (3) Undang-Undang Keterbukaan Informasi Publik menyebabkan anggaran publik mudah diakses oleh masyarakat sehingga meningkatkan transparansi dan akuntabilitas berorientasi partisipasi publik; (4) Pemkot Kupang memiliki website untuk mempublikasikan kinerja berbasis anggaran; (5) Pemkot Kupang memiliki sumber daya personil dan peralatan tugas pemerintah yang memadai. Sementara itu, kelemahannya terdiri atas: (1) Fungsi Badan Inspektorat tergantung pada keinginan kepala daerah karena pertanggungjawaban kinerjanya adalah walikota, demikian juga SPI yang diharapkan sebagai pengendali dan penilaian kinerja personil tidak berjalan maksimal; (2) Kemitraan Forkompimda memengaruhi penegakan hukum di daerah; (3) Website hanya menjadi fungsi kegiatan pengadaan dalam APBD dan fungsi informasi, belum diikuti penerapan penyediaan dokumen APBD elektronik; (4) Walikota dan pimpinan dinas sulit melakukan evaluasi terhadap kinerja personil karena perilaku korupsi dipengaruhi faktor individu, organisasi, maupun campuran keduanya; (5) Modus korupsi terkait erat dengan kewenangan tugas dan fungsi jabatan sehingga sulit dalam pemantauan pungli dan suapmenyuap yang terjadi; (6) Kota Kupang merupakan kota terkorup di Indonesia; (7) Transaksi anggaran di pemerintahan masih bersifat manual; dan (8) Pungli masih tinggi di Kota Kupang (Habaora, 2015ab; 2016ab; \& 2017).

Selain faktor internal di atas, ada faktor eksternal yang patut dipertimbangkan, yaitu peluang yang dimiliki Pemkot Kupang, yang terdiri atas: (1) Pengelolaan anggaran daerah diawasi oleh masyarakat dan aparat penegak hukum (Komisi Pemberantasan Korupsi, Badan Pemeriksa Keuangan, Pusat Pelaporan dan Analisis Transaksi Keuangan, Kepolisian, Kejaksaan, NGO/ LSM, media massa, dan masyarakat); (2) Era digitalisasi memudahkan akses informasi dan pengawasan publik; (3) Nawacita Revolusi Mental yang digagas oleh Pemerintah Republik Indonesia untuk memberantas korupsi sampai ke daerahdaerah; (4) Seluruh pengelolaan proyek 
dan tender melalui internet (LPSE); (5) Ratusan kasus terjaring Operasi Tangkap Tangan Komisi Pemberantasan Korupsi Republik Indonesia (OTT KPK), termasuk kepala daerah dan ASN. Sementara itu, pencegahan dan pemberantasan korupsi oleh Pemkot Kupang dapat terancam oleh: (1) Kemajuan informasi dan teknologi serta pengalaman membentuk strategi baru menyembunyikan korupsi dalam organisasi, seperti pada pelelangan proyek di pemerintahan; (2) Tim sukses yang selalu membayangi kinerja pemerintahan karena kepentingan balas jasa; (3) Penegakan hukum yang lemah karena kongkalikong, gratifikasi, dan tekanan politik.

Jika semua faktor di atas disusun dalam matriks, akan tergambar kekuatan

Tabel 1.

Matrik SWOT Pencegahan dan Pemberantasan Korupsi di Pemerintah Kota Kupang

\begin{tabular}{|c|c|c|c|}
\hline & & $\begin{array}{l}\text { Kekuatan } \\
\text { 1) Pemkot Kupang memiliki Badan } \\
\text { Inspektorat dan Satuan Pengendali } \\
\text { Internal untuk mengawasi dan } \\
\text { pencegahan tindakan korupsi di } \\
\text { kelembagaan pemerintah. } \\
\text { 2) Walikota (Kepala Daerah) memiliki } \\
\text { kelembagaan pimpinan daerah } \\
\text { (Forkopimda) bersama Kejaksaan, } \\
\text { Pengadilan Negeri, dan Kepolisian } \\
\text { sehingga mudah untuk memorandum } \\
\text { of understanding (MoU) atau kerja sama } \\
\text { dalam pemantauan korupsi. } \\
\text { 3) Undang-Undang Keterbukaan Informasi } \\
\text { Publik menyebabkan anggaran publik } \\
\text { mudah diakses oleh masyarakat. } \\
\text { 4) Pemkot Kupang memiliki website untuk } \\
\text { mempublikasikan kinerja berbasis } \\
\text { anggaran. } \\
\text { 5) Pemkot Kupang memiliki sumber daya } \\
\text { personil dan peralatan tugas pemerintah } \\
\text { yang memadai. }\end{array}$ & $\begin{array}{l}\text { Kelemahan } \\
\text { 1) Fungsi Badan Inspektorat tergantung } \\
\text { pada keinginan kepala daerah karena } \\
\text { pertanggungjawaban kinerjanya adalah } \\
\text { Walikota, demikian juga SPI yang diharapkan } \\
\text { sebagai pengendali dan penilaian kinerja } \\
\text { personil tidak berjalan maksimal. } \\
\text { 2) Kemitraan Forkopimda memengaruhi } \\
\text { penegakan hukum di daerah; } \\
\text { 3) Website hanya menjadi fungsi kegiatan } \\
\text { pengadaan dalam APBD dan fungsi informasi, } \\
\text { belum diikuti penerapan penyediaan dokumen } \\
\text { APBD elektronik; } \\
\text { 4) Walikota dan pimpinan Dinas sulit melakukan } \\
\text { evaluasi terhadap kinerja personil karena } \\
\text { perilaku korupsi dipengaruhi faktor individu, } \\
\text { organisasi, maupun campuran keduanya; } \\
\text { 5) Modus korupsi terkait erat dengan kewenangan } \\
\text { tugas dan fungsi jabatan sehingga sulit dalam } \\
\text { pemantauan pungli dan suap-menyuap yang } \\
\text { terjadi } \\
\text { 6) Kota Kupang merupakan kota terkorup di } \\
\text { Indonesia. } \\
\text { 7) Transaksi anggaran di pemerintahan masih } \\
\text { bersifat manual. } \\
\text { 8) Pungli masih tinggi di Kota Kupang. }\end{array}$ \\
\hline & $\begin{array}{l}\text { 2) } \\
\text { 3) }\end{array}$ & $\begin{array}{l}\text { Peluang } \\
\text { Pengelolaan anggaran daerah diawasi oleh } \\
\text { masyarakat dan aparat penegak hukum (Komisi } \\
\text { Pemberantasan Korupsi, Badan Pemeriksa } \\
\text { Keuangan, Pusat Pelaporan dan Analisis } \\
\text { Transaksi Keuangan, Kepolisian, Kejaksaan, } \\
\text { NGO/LSM, media massa, dan masyarakat); } \\
\text { Era digitalisasi memudahkan akses informasi } \\
\text { dan pengawasan publik; } \\
\text { Nawacita Revolusi Mental yang digagas } \\
\text { oleh Pemerintah Republik Indonesia untuk } \\
\text { memberantas korupsi sampai ke daerah- } \\
\text { daerah; } \\
\text { Seluruh pengelolaan proyek dan tender melalui } \\
\text { internet (LPSE); } \\
\text { Ratusan kasus terjaring Operasi Tangkap } \\
\text { Tangan Komisi Pemberantasan Korupsi } \\
\text { Republik Indonesia (OTT KPK), termasuk kepala } \\
\text { daerah dan ASN. }\end{array}$ & \begin{tabular}{l}
\multicolumn{1}{c}{ Ancaman } \\
1) Kemajuan informasi dan \\
teknologi serta pengalaman \\
membentuk strategi baru \\
menyembunyikan korupsi \\
dalam organisasi, seperti \\
pada pelelangan proyek di \\
pemerintahan. \\
2) Tim sukses yang selalu \\
membayangi kinerja \\
pemerintahan karena \\
kepentingan balas jasa. \\
3) Penegakan hukum yang \\
lemah karena kongkalikong, \\
gratifikasi, dan tekanan politik.
\end{tabular} \\
\hline
\end{tabular}


(strengths), kelemahan (weaknesses), kesempatan (opportunity), dan ancaman (threat). Penggunaan matriks SWOT di sini dimaksudkan untuk membantu mengambil keputusan dalam menentukan strategi yang akan digunakan.

Berbekal analisis SWOT di atas, maka penulis menilai ada beberapa strategi yang dapat dilakukan dalam rangka pencegahan dan pemberantasan korupsi di Pemerintahan Kota Kupang, yaitu:

Pertama, membuat Memorandum of Understanding (MoU) dengan lembaga penegakan hukum. Kebijakan pemberantasan korupsi melalui MoU merupakan suatu langkah tepat karena akan memfokuskan locus dari penanganan korupsi di antara kedua belah pihak. Penulis menyadari bahwa KPK memiliki kelemahan jangkauan sampai ke daerahdaerah. Oleh karena itu, jika Pemkot membuat MoU dengan KPK diharapkan semakin tercipta good governance dalam pengelolaan anggaran publik di daerah. MoU merupakan suatu nota kesepahaman yang dibuat antara subjek hukum yang lainnya, baik dalam suatu negara atau antarnegara untuk melakukan kerja sama dalam berbagai aspek kehidupan dan jangka waktunya tertentu (Novianti, 2014: 235). MoU adalah dokumen yang memuat saling pengertian dan pemahaman para pihak sebelum dituangkan dalam perjanjian yang formal yang mengikat kedua belah pihak. Alangkah baiknya jika MoU dituangkan kembali dalam suatu model perjanjian. MoU yang dilakukan Pemkot Kupang tidak saja dilakukan terhadap Komisi Pemberantasan Korupsi namun perlu dilakukan juga kepada pihak Kepolisian, Kejaksaan, BPK, dan Pengadilan. Semakin banyak lembaga yang mengawasi dalam pengelolaan anggaran publik akan semakin baik (Habaora, 2015a: 131).

Kedua, menyelenggarakan transaksi keuangan berbasis elektronik di pemerintahan. Pembayaran yang masih bersifat manual cenderung terjadi kesalahan dan duplikasi pembayaran, seperti pembayaran gaji aparatur, dan lain sebagainya. Selain itu, pembayaran secara manual dapat menyebabkan pemotongan gaji aparatur dengan alasan ketiadaan sejumlah uang recehan. Secara hukum tindakan ini merupakan perilaku korupsi. Untuk mewujudkan pembayaran yang tepat waktu dan cepat, dapat difasilitasi dengan sistem pembayaran secara elektronik. Pembayaran secara elektronik dapat mendukung penyelenggaraan administrasi publik yang efisien dan efektif. Jika proses administrasi publik efisien dan efektif maka ekonomi akan lebih berdaya saing. Transaksi secara elektronik juga dapat dilakukan pada penagihan-penagihan yang dilakukan oleh pemerintah kepada pihak ketiga, seperti pada retribusi parkir dan Pajak Bumi Bangunan (PBB) di Kota Kupang yang masih dilakukan secara manual. Hal ini untuk mengatasi indikasi korupsi pada laporan pertanggungjawaban kinerja dari Dinas (contohnya Dinas Perhubungan dan Dinas Pendapatan Daerah) di Kota Kupang yang selama ini dianggap tidak sesuai besaran jumlah uang yang cukup besar dari penagihan yang dilakukan oleh dinas tersebut. Model penagihan elektronik ini dapat dikembangkan pada keseluruhan dinas dalam melakukan transaksi keuangan dengan Pemkot Kupang. Transaksi elektronik (online) melalui bank atau ATM akan meniadakan kesalahan data, menghindari proses duplikasi tagihan, dan duplikasi proses tagihan, manajemen arsip lebih sederhana, dan staf dapat diarahkan untuk aktivitas yang lebih bermanfaat. Implementasi area bebas korupsi pun semakin baik karena mengurangi kecurangan, pelaporan dan audit lebih mudah, cepat dan akurat.

Ketiga, membentuk gugus tugas pemberantasan pungli di pemerintahan. Pungli merupakan perbuatan yang dilakukan oleh seseorang atau pegawai negeri atau pejabat negara dengan cara meminta pembayaran sejumlah uang 
yang tidak sesuai atau tidak berdasarkan peraturan yang berkaitan dengan pembayaran tersebut (Ramadhani, 2017: 267). Adanya pengawasan pemerintah melalui kerja sama dengan aparat penegak hukum semakin efektif mengurangi pungli yang selama ini masih terjadi di Pemkot Kupang karena dilakukan oleh pejabat-pejabat pemerintahan. Strategi membentuk tim cyber pungli di Pemkot Kupang merupakan tindakan efektif mengurangi perilaku korupsi di daerah tersebut. Afiliasi Pemkot Kupang dengan Komisi Ombudsman Nasional perlu dipertimbangkan dalam penyusunan tim gugus tugas cyber pungli karena selain memberantas pungli, juga untuk perbaikan manajemen pemerintahan dari pembinaan yang dilakukan oleh Ombudsman.

Keempat, memberlakukan pelaporan keuangan pada pejabat di lingkup pemerintahan. Pelaporan harta kekayaan pejabat publik melalui mekanisme Laporan Harta Kekayaan Penyelenggara Negara (LHKPN) yang diatur sebagai kewajiban Penyelenggara Negara berdasarkan Undang-Undang Nomor 28 Tahun 1999 menjadi landasan utama kewajaran kepemilikan aset dan kekayaan yang dimiliki oleh seorang pejabat publik berdasarkan pendapatan yang sah yang dimilikinya (Palma, Abid, Martini, Alim, \& Diansyah, 2014). Selama ini implementasi hal tersebut di Kota Kupang belum ada sehingga Pemkot Kupang perlu memberlakukan setiap pejabat yang ada di lingkup Pemkot Kupang melaporkan harta kekayaan pejabat. Laporan harta kekayaan menjadi pintu masuk mengukur kekayaan dan pendapatannya didapat dari sumber yang sah. Seorang pejabat publik apabila diduga memiliki kekayaan melebihi dari sumber pendapatannya harus dapat membuktikan dirinya tidak mendapatkan kekayaan dan pendapatannya dari hasil yang tidak sah. Untuk itu sangat diperlukan sekali pelaporan kekayaan dari pejabat publik sebagai penyelenggara negara. LHKPN dapat meningkatkan terbangunnya budaya anti korupsi dan berkurangnya korupsi karena pejabat dituntut jujur, terbuka dan bertanggung jawab, merasa diawasi, rasa takut berbuat korupsi, dan juga sebagai sarana kontrol masyarakat.

Kelima, meningkatkan efisiensi anggaran pemerintahan yang ganda fungsi dan tidak bermanfaat. Efisiensi anggaran berdampak pada efektivitas dan efisiensi pelayanan publik. Efektivitas terkait dengan pencapaian tujuan dari Satuan Kerja Perangkat Daerah (SKPD), dan efisiensi pelayanan publik terkait dengan usaha minimal untuk mencapai suatu tingkat tertentu dari tujuan SKPD (Suparno \& Nanda, 2016: 115; Ferryono \& Sutaryo, 2017: 155). Dengan demikian, efisiensi anggaran pada SKPD-SKPD menyebabkan penghematan anggaran publik dan meningkatkan pengembangan pelayanan publik secara efektif dan efisien sehingga SKPD dapat memenuhi tujuannya tanpa membebani anggaran tahun berjalan.

Membuka akses pemantauan publik melalui pangkalan data elektronik. Salah satu manfaat era globalisasi adalah untuk memudahkan akses publik terhadap informasi publik. Salah satu metadata yang dapat dipergunakan adalah website. Pradana (2014: 204) melaporkan bahwa tingkat sekresi/kerahasiaan informasi pengelolaan Anggaran Pendapatan dan Belanja Daerah (APBD) Pemkot Kupang sangat tinggi sehingga sulit diakses oleh publik, seperti dokumen Rencana Kerja dan Anggaran (RKA), Dokumen Pelaksanaan Anggaran (DPA) dan Laporan Realisasi Anggaran (LRA) merupakan rahasia negara sehingga perlu mendapatkan persetujuan/ rekomendasi dari kepala daerah jika akan diakses oleh publik. Hal ini disebabkan oleh beberapa hal, yaitu permasalahan sosialisasi, ketiadaan perangkat hukum yang mengatur mengenai infrastruktur di bidang keterbukaan informasi publik, dan ketiadaan sumber daya serta adanya persepsi yang dimiliki oleh sebagian besar birokrat Pemkot Kupang mengenai kerahasiaan dokumen pengelolaan APBD. 
Oleh karena itu peran walikota Kupang untuk membuka akses publik melalui basis data elektronik seperti dokumen anggaran merupakan solusi terbaik untuk meningkatkan fungsi kontrol masyarakat dalam pemberantasan korupsi di Kota Kupang.

Keenam, melakukan pengukuran kinerja berbasis pakta integritas. Pakta integritas merupakan surat pernyataan yang berisi ikrar untuk mencegah dan tidak melakukan kolusi, korupsi, dan nepotisme. Ansari (2016: 385) menyatakan bahwa pengaturan pakta integritas di pemerintahan merupakan salah satu upaya untuk mewujudkan pemerintahan yang baik dan bersih (good governance and clean government). Namun, yang lebih penting adalah penerapan materi dari ikrar untuk mencegah dan tidak melakukan kolusi, korupsi, dan nepotisme. Pemkot Kupang perlu mempertimbangkan implementasi pakta integritas dalam setiap pelaksanaan kebijakan pemerintah, seperti saat melakukan mutasi-demosi dan reward-punishment.

Keseluruhan strategi dalam upaya pencegahan dan pemberantasan korupsi di Kota Kupang dapat disebar dan dilakukan dalam visi misi kepala daerah, maupun implementasi program pemerintah. Usaha mencegah dan memberantas korupsi, sangat dipengaruhi juga oleh faktor leading (kepemimpinan). Strategi ini jika diimplementasikan berdampak pada pencegahan dan pemberantasan korupsi di Kota Kupang. Hasilnya, masyarakat semakin sejahtera dan keadilan pelayanan publik semakin tertata baik di Pemkot Kupang.

\section{Penutup}

Korupsi adalah tindakan untuk memperkaya diri, keluarga, kelompok, dan korporasinya dengan cara melanggar aturan, melanggar norma, melanggar hak asasi manusia melalui eksploitasi sumber daya ekonomi, politik, sosial budaya, dan lingkungan hidup dengan memaksimalkan potensi sumber daya yang dimiliki (jabatan, jaringan, dan kekuasaan). Faktor penyebab korupsi di Kota Kupang adalah motivasi individu dan sistem organisasi pemerintah yang buruk, dan akan semakin meningkat pengaruh korupsi jika didukung oleh lingkungan di mana individu dan sistem yang buruk berada. Berdasarkan hal tersebut maka rekomendasi strategi yang dapat dilakukan oleh Pemkot Kupang adalah: (1) Membuat Memorandum of Understanding dengan lembaga penegakan hukum; (2) Menyelenggarakan transaksi keuangan berbasis elektronik di pemerintahan; (3) Membentuk gugus tugas pemberantasan pungli di pemerintahan; (4) Memberlakukan pelaporan keuangan pada pejabat di lingkup pemerintahan; (5) Meningkatkan efisiensi anggaran pemerintahan yang ganda fungsi dan tidak bermanfaat; (6) Membuka akses pemantauan publik melalui basis data elektronik; dan (7) Melakukan pengukuran kinerja berbasis pakta integritas. Strategi ini jika diimplementasikan dalam visi dan program Pemkot Kupang berdampak pada pencegahan dan pemberantasan korupsi di Kota Kupang sehingga masyarakat semakin sejahtera dan keadilan pelayanan publik semakin tertata baik.

\section{Daftar Pustaka}

Ama, K. K. \& Haryo PS, C. W. (2010, Mei 25). Otonomi daerah NTT: gurita korupsi di daerah miskin. Diakses dari https:// antikorupsi.org/id/newsotonomi-daerahntt-gurita-korupsi-di-daerah-miskin/.

Ansari, M. I. (2016). Integrity pact implementation of procurement of goods/ services to realize that clean government. Kanun Jurnal IImu Hukum, 18(3), 385-401.

Assegaf, F. (2009, Januari 21). Kupang, kota paling korup di Indonesia. tempo.co. Diakses dari https://nasional.tempo.co/ read/156263/kupang-kota-paling-korupdi-indonesia. 
Badan Pengawas Keuangan dan Pembangunan. (2002). Upaya pencegahan dan penanggulangan korupsi pada pengelolaan APBN/APBD. Diakses dari http://www.bpkp.go.id/public/upload/unit/ investigasi/files/uppk_bumn_bumd.pdf.

Bauhr, M. \& Nasiritousi, N. (2011). Why pay bribes? Collective action and anti corruption efforts. (Working Paper Series 2011: 18). Diakses dari https:// www.sahlgrenska.gu.se/digitalAsse ts/1357/1357856_2011_18_bauhr_ nasiritousi.pdf.

Fauzan, M., Bahtaruddin, \& Nuraini, $H$. (2012). Implementasi pemerintahan yang bersih dalam kerangka rencana aksi daerah pemberantasan korupsi: studi di Kabupaten Pemalang. Jurnal Dinamika Hukum, 12(3), 448-463.

Ferryono, B. \& Sutaryo. (2017). Manfaat akuntansi basis akrual dan akuntansi basis kas menuju akrual dalam pengambilan keputusan internal pemerintah daerah. Jurnal Dinamika Akuntansi dan Bisnis, 4(1), 143-160.

Habaora, F. (2015a). Populasi Opini Penyalahgunaan Kekuasaan. Yogyakarta: Deepublish Press.

Habaora, F. (2015b). Inspirasi Pendidikan Politik. Jakarta: Penerbit JP II Publishing House.

Habaora, I. (2016a, Agustus 23). Mengurai tabir PD Sasando: Smart City solusinya. zonalinenews.com. Diakses dari https:// www.zonalinenews.com/2016/08/ mengurai-tabir-pd-sasando-smart-citysolusinya/.

Habaora, I. (2016b, Oktober 23). 10 dugaan Jonas Salean, muluskan Firmanmu pimpin Kota Kupang. Diakses dari http://www. penanusantara.com/10-dugaan-jonassalean-muluskan-firmanmu-pimpin-kotakupang/.

Habaora, I. (2017, Juli 18). Analisis masalah penerimaan peserta didik baru (PPDB) di Kota Kupang. Diakses dari http://www. ayananews.com/2017/07/18/analisismasalah-penerimaan-perserta-didik-baruppdb-di-kota-kupang/.
Hariyanto. (2012). Priayisme dan korupsi kolusi nepotisme (KKN): Studi status group di Kabupaten Sleman Provinsi Daerah Istimewa Yogyakarta. Aspirasi: Jurnal Masalah-Masalah Sosial, 3(2): 11-129.

Herdiana, D. (2019). Kecenderungan perilaku koruptif kepala desa dalam pembangunan desa. Matra Pembaharuan: Jurnal Inovasi Kebijakan, 3(1), 1-11. doi: 10.21787/ mp.3.1.2019.1-11

Ini dia peringkat provinsi terkorup di Indonesia versi FITRA. (2012, Oktober 1). detik. com. Diakses dari https://news.detik.com/ berita/2047460/ini-dia-peringkat-provinsiterkorup-di-indonesia-versi-fitra.

Jahang, B. (2020, Januari 28). 3 kasus korupsi ditangani Polres Kupang Kota. antaranews. com. Diakses dari https://kupang. antaranews.com/berita/27905/3-kasuskorupsi-ditangani-polres-kupang-kotal.

Kaha, K. (2018, Desember 11). Polisi tahan dua kepsek selewengkan dana BOS. antaranews.com. Diakses dari https:// kupang.antaranews.com/berita/10386/ polisi-tahan-dua-kepsek-selewengkandana-bos.

Novianti. (2014). Position of memorandum of understanding between Indonesia with International Committee of Red Cross (ICRC) linked to humanitarian relief based on international law perspective. Jurnal Negara Hukum: Membangun Hukum Untuk Keadilan, 5(2), 223-238. doi: 10.22212/jnh. v5i2.242

Palma, A. K., Abid, L., Martini, S., Alim, H., \& Diansyah, F. (2014). Implementasi dan pengaturan illicit enrichment (Peningkatan kekayaan secara tidak sah) di Indonesia. Jakarta: ICW Press.

Panjaitan, B. (2018, Oktober 17). Partisipasi Masyarakat Dalam Pemberantasan Korupsi [Power Point Slide]. Diakses dari https://unwidha.ac.id/wp-content/ uploads/2018/10/materi-kuliah-UmumKPK-Unwidha-2018.pdf.

Pope, J. (2000). Confronting corruption: The elements of a national integrity system. Berlin: Transparency International Press.

Portal NTT (Ed.). (2016, November 3). Warga jalan nangka dan Firmanmu siap ratakan 
korupsi di Kota Kupang. PortalNTT.com. Diakses dari http://www.portalntt.com/ warga-jalan-nangka-dan-firmamu-siapratakan-korupsi-di-kota-kupang/.

Pradana, I. P. Y. B. (2014). Transparansi birokrasi dalam pengelolaan APBD Kota Kupang. Jurnal Kebijakan dan Administrasi Publik, 18(2), 185-205.

Rangkuti, F. (2006). Analisis SWOT Teknik Membedah Kasus Bisnis: Reorientasi Konsep Perencanaan Strategis untuk Menghadapi Abad 21. Jakarta: PT. Gramedia Pustaka Utama.

Ramadhani, W. (2017). Penegakan hukum dalam menanggulangi pungutan liar terhadap pelayanan publik. Jurnal Hukum Samudra Keadilan, 12(2), 263-276.

Rambu, B. (2018a, Maret 23). Korupsi Wali Kota Cup 2017 Naik Status. Victory News. Diakses dari https://www.victorynews.id/ korupsi-wali-kota-cup-2017-naik-status/.

Rambu, B. (2018b, Maret 14). Pelaku korupsi di NTT terbanyak ASN. Victory News. Diakses dari https://www.victorynews.id/ pelaku-korupsi-ntt-terbanyak-asn/.

Redaksi Timor. (2016, April 29). NTT urutan 4 terbanyak korupsi. Timor Express. Diakses dari https://timorexpress.fajar. co.id/2016/04/29/ntt-urutan-4-terbanyakkorupsi/.

Retnowati, Y. \& Utami, Y. S. (2014). Relevansi gerakan anti korupsi untuk pembangunan. Jurnal Paradigma, 18(1), 28-38. doi: 10.31315/paradigma.v18i1.2406

Rothstein, B., \& Varraich, A. (2014). Corruption and the opposite to corruption: A map of the conceptual landscape. Sweden: University of Gothenburg Press. Diakses dari https://anticorrp.eu/wp-content/ uploads/2014/12/D1.1_Part1_Corruptionand-the-Opposite-to-Corruption.pdf.

Setiyono, B. (2017). Understanding corruption at local level post decentralization: Evidence from four case studies. Politika: Jurnal IImu Politik, 8(1), 27-62. doi: 10.14710/politika.8.1.2017.27-62

Shah, A. \& Schacter, M. (2004). Combating corruption: look before you leap. Finance and Development, 41(4), 40-43.
Strauss, A. \& Corbin, J. (2009). Dasar-Dasar Penelitian Kualitatif. Yogyakarta: Pustaka Belajar Press.

Suparno \& Nanda, R. (2016). Pengaruh kemandirian keuangan daerah, diferensiasi fungsional dan spesialisasi fungsional terhadap tingkat pengungkapan wajib laporan keuangan pemerintah daerah. Jurnal Dinamika Akuntansi dan Bisnis, 3(2), 105-118.

Tashandra, N. (2016, Februari 24). ICW: Sepanjang tahun 2015, anggaran negara 134 kali dikorupsi. kompas.com. Diakses dari https://nasional.kompas. $\mathrm{com} / \mathrm{read} / 2016 / 02 / 24 / 17044021 / \mathrm{ICW}$. Sepanjang.Tahun.2015. Anggaran . Negara.134.Kali.Dikorupsi.

Terindikasi KKN, Pokja ULP Dinas PU-PR Kota Kupang dilaporkan ke Kejati NTT. (2020, Juni 6). Diakses dari http://www.expontt. com/terindikasi-kkn-pokja-ulp-dinas-pupr-kota-kupang-dilaporkan-kejati-ntt/.

Wahyono. (2019, Januari 15). Politik dinasti di Indonesia dalam cengkraman politik. sindonews.com. Diakses dari https://nasional.sindonews.com/ read/1370481/12/politik-dinasti-indonesiadalam-cengkeraman-korupsi-1547480071.

World Bank. (2003). Youth for good governance, distance learning program (Module IV). Washington: World Bank Press. 